\title{
PENINGKATAN KINERJA PADA PROSES PRODUKSI KERIPIK PARU DAN UNTHUK YUYU
}

\author{
Increasing Production Efficiency of Beef Lung Crackers and Unthuk Yuyu \\ Hera Sisca Prasmita dan Jhauharotul Muchlisyiyah \\ Jurusan Teknologi Hasil Pertanian - Universitas Brawijaya, Jl. Veteran, Malang \\ email : herasisca87@ub.ac.id
}

\begin{abstract}
Beef lungs chips and unthuk yuyu are local snack from Kanigoro, Blitar, East Java. Beef lungs chips is made of beef lungs that boiled and stored in freezer. Frozen beef lungs is cut into pieces, dipped in spices, coated in flour and then fried in oil until golden. Unthuk yuyu is local snack made of glutinous rice flour, eggs, sugar and coconut milk. The process of making unthuk yuyu are all ingredients are mixed and then molded using cake mold that specific for unthuk $y u y u$, and the last is fried this molded dough until golden. The problems of producing beef lungs chips are the low capacity of frying beef lungs and still using conventional knife to cut the beef lungs. The problems of producing untruk yuyu are butter mixing still use small mixer, sugar grinding and coconut shreding still using traditional implementation and need more labour. There are several solution to overcome those problems by introduce the new advance technology in food processing After introduction of meat slicer and high pressure stove in beef lungs chips processing can increase the efficiency and capacity of cutting frozen beef lungs four times higher and increase of frying capacity two times higher than before. By introducing of grinding meachine, shreding meachine and planetary mixer also can increase the efficiency and capacity of producing untruk yuyu. By using planetary mixer $15 \mathrm{~L}$ in size, the capacity of mixing process could be increase.
\end{abstract}

Keywords: production capacity, beef lungs chips and unthuk yuyu

\begin{abstract}
ABSTRAK
Keripik paru dan unthuk yuyu merupakan makanan khas camilan di Kecamatan Kanigoro, Blitar. Keripik paru merupakan produk dari paru sapi yang direbus, dibekukan, diiris tipis, diberi bumbu, kemudian digoreng dengan penyalut tepung hingga kering. Undruk yuyu merupakan makanan khas yang dibuat dari tepung ketan, telur, gula, dan santan yang diadoni dan dicetak panjang, kemudian digulung dan digoreng. Permasalahan yang dihadapi dalam produksi keripik paru yaitu kapasitas penggorengan yang rendah dan pemotongan paru yang masih menggunakan pisau manual. Sedangkan kendala pada produksi undruk yuyu adalah kapasitas pengadukan adonan, penggilingan gula dan pemarutan kelapa yang masih rendah. Solusi yang ditawarkan untuk mengatasi permasalahan tersebut adalah alih teknologi proses produksi keripik paru dan untruk yuyu. Adapun hasil dari kegiatan tersebut adalah peningkatan efisiensi pemotongan paru beku menggunakan pemotong daging beku menjadi 4 kali lipat dibandingan menggunakan pisau manual. Peningkatan kapasitas penggorengan menggunakan kompor jos menjadi 2 kali lipat dibandingkan menggunakan kompor bertekanan rendah. Adanya peningkatan kapasitas dan efisiensi produksi unthuk yuyu dengan cara introduksi menggunakan mesin pemarutan kelapa, penggiling gula dan pengaduk adonan (planetary mixer). Penggunaan mixer ukuran 15 liter juga meningkatkan kapasitas pengadukan adonan.
\end{abstract}

Kata kunci: Kapasitas produksi, keripik paru, unthuk yuyu 


\section{PENDAHULUAN}

Keripik paru sapi adalah makanan kering yang dibuat dari paru sapi ( Bos indicus) memiliki rasa yang gurih dan renyah yang diolah dengan cara perebusan, diiris tipis sehingga berbentuk lempeng, diberi bumbu kemudian digoreng dengan atau tanpa penambahan tepung (SNI 014280-1996). Produk keripik paru merupakan hasil olahan industri rumah tangga yang dalam memproduksi masih sederhana. Salah satu UKM yang memproduksi keripik paru adalah UKM "Madinah" Kanigoro, Blitar (Wulandari, 2012).

Bahan baku pembuatan keripik paru berasal dari paru sapi. Paru-paru merupakan komponen offal (jeroan) yang belum banyak dimanfaatkan sebagai sumber protein. Jaringan tersebut mengandung tinggi protein (Goldstrand, 1988). Nilai komposisi kimia paru sapi segar mengandung $77 \%$ air, $4,2 \%$ lemak, $18 \%$ protein dan $1 \%$ abu (Campos dan Areas, 1993). Adapun kadar protein yang sudah dikeringkan menggunakan oven meningkat sebesar $74,8 \%$ protein.

Secara umum proses pembuatan keripik yaitu pengirisan bahan, pemberian bumbu, melapisi dengan tepung dan penggorengan, tetapi ada pula yang dilakukan penjemuran atau pengeringan (BSN, 1996)

Selain keripik paru, daerah Kanigoro Blitar juga memiliki makanan cemilan khas yaitu untruk yuyu. Menurut Suhartini dan Hidayat (2005) kue unthuk yuyu juga dikenal dengan kue ulat sutera. Kue ini merupakan jajanan ringan berbahan dasar tepung ketan, santan, gula, garam dan air. Bentuknya seperti ulat karena dalam proses pencetakan menggunakan cetakan dawet sehingga dapat berbentuk spiral setelah itu baru digoreng dengan minyak. Rasa dari kue unthuk yuyu ini renyak, manis dan gurih.

UKM atau usaha mikro, kecil, menengah tersebut telah menunjukkan perannya, namun masih menghadapi berbagai kendala dan hambatan baik yang bersifat internal dan eksternal dalam hal produksi dan pengolahan, pemasaran, sumberdaya manusia, desain dan tehnologi, permodalan serta iklim usah (Prayekti dan Herawati, 2014). Seperti pada UKM Madinah yang memproduksi keripik paru masih terkendala proses pengirisan paru yang masih menggunakan pisau manual sehingga kapasitas produksi terbatas. Adapun UKM Sanora yang memproduksi unthuk yuyu juga mengalami kendala proses produksi yang masih menggunakan alat yang sederhana seperti pemarutan kelapa, penggilingan gula dan pengadukan adonan. Oleh karena itu perlu dilakukan introduksi penggunaan mesin pengolahan yang lebih mudah pengoperasiannya dan dapat meningkatkan efisiensi dan kapasitas produksi.

\section{METODE PELAKSANAAN}

Pelaksanaan kegiatan IbM ini ditujukan untuk menyelesaikan masalahmasalah yang dihadapi mitra dalam memproduksi keripik paru dan undruk yuyu di daerah Kanigoro, Blitar. Metode pelaksanaannya adalah sebagai berikut:

\section{Peningkatan kapasitas penggorengan keripik paru}

Pada proses pengolahan keripik paru, paru setelah direbus lalu dibekukan. Dalam satu hari produksi mitra menggunakan paru sapi mentah sebanyak $10 \mathrm{~kg}$. Untuk membekukan. Mitra 1 masih menggunakan kompor gas rumah tangga dengan tekanan gasnya rendah sehingga proses penggorengan memakan waktu lama. Akibatnya mitra tidak bisa meningkatkan kapasitas produksinya karena keterbatasan lama waktu penggorengan. Solusi yang ditawarkan adalah alih teknologi menggunakan kompor jos bertekanan tinggi.

\section{Peningkatan kapasitas and efisiensi pemotongan paru sapi beku}

Proses pemotongan harus pada kondisi beku sehingga pemotongan bisa bagus hasilnya. Mitra 1 melakukan proses pemotongan secara manual. Kelemahan pemotongan manual ini adalah irisan paru tidak merata, pemotongan sulit karena paru 
keras akibat beku, memakan tenaga cukup besar karena keras, pisau yang digunakan harus sangat tajam, dan kesulitan memegang paru beku akibat sangat dingin. Proses pemotongan memakan waktu lama karena untuk $5 \mathrm{~kg}$ paru dibutuhkan waktu 2-3 jam, sehingga untuk $10 \mathrm{~kg}$ paru/hari dibutuhkan waktu pemotongan 4-6 jam. Pemotongan ini merupakan bottle neck pada proses produksi keripik paru. Oleh karena itu perlu alih teknologi menggunakan mesin meat slicer untuk dapat mengatasi kendala pemotongan menggunakan pisau manual.

\section{Peningkatan kapasitas pemarutan kelapa}

Proses pengolahan undruk yuyu adalah dimulai dengan pemarutan kelapa dan pembuatan santan. Dalam satu hari produksi Mitra 2 membutuhkan kelapa sebanyak 15 butir kelapa yang membutuhkan waktu pemarutan sampai 75 menit. Selama ini Mitra 2 menggunakan mesin pemarut kecil bertenaga dinamo untuk memarut kelapa dan kapasitasnya juga kecil, selain itu pengoperasiannya juga cukup rumit. Untuk mengatasi kelemahan ini diperlukan alih teknologi menggunakan mesin pemarut listrik.

\section{Peningkatan kapasitas penepungan gula}

Proses produksi untruk yuyu juga menggunakan bahan baku gula halus. Sementara itu harga gula halus relatif lebih tinggi yaitu Rp 18.000,- sampai Rp 25.000,bila dibandingkan dengan gula pasir dengan harga Rp 12.000,- sampai Rp 15.000,-. Sehingga Mitra 2 menggilingkan gula pasir melalui jasa penggilingan dengan harga Rp 1000,- setiap $1 \mathrm{~kg}$ gula pasir. Akibatnya biaya produksi meningkat dan dirasa kurang efektif karena harus berkalikali ke tempat penggilingan. Oleh karena itu diperlukan mesin penggiling tepung untuk dapat meningkatkan kapasitas dan efisiensi penggilingan gula.

\section{Peningkat kapasitas pengaduakan adonan untruk yuyu}

Pengadukan adonan yang dilakukan di Mitra 2 menggunakan mixer kecil untuk skala rumah tangga. Proses pengadukan ini memakan waktu 1 jam karena kapasitas pengadukan $1,5 \mathrm{~kg}$ untuk 15 menit. Sehingga diperlukan mixer dengan kapasitas besar utuk dapat meningkatkan kapasitas pengadukan adonan untruk yuyu.

\section{HASIL DAN PEMBAHASAN}

\section{Peningkatan kapasitas penggorengan keripik paru}

Setelah introduksi penggunaan kompor jos bertekanan tinggi untuk menggoreng keripik paru terbukti dapat mempercepat proses penggorengan yang awalnya memakan waktu 1 jam untuk menggoreng paru sebanyak $1,5 \mathrm{~kg}$, menjadi hanya memerlukan waktu setengah jam (Tabel.1)

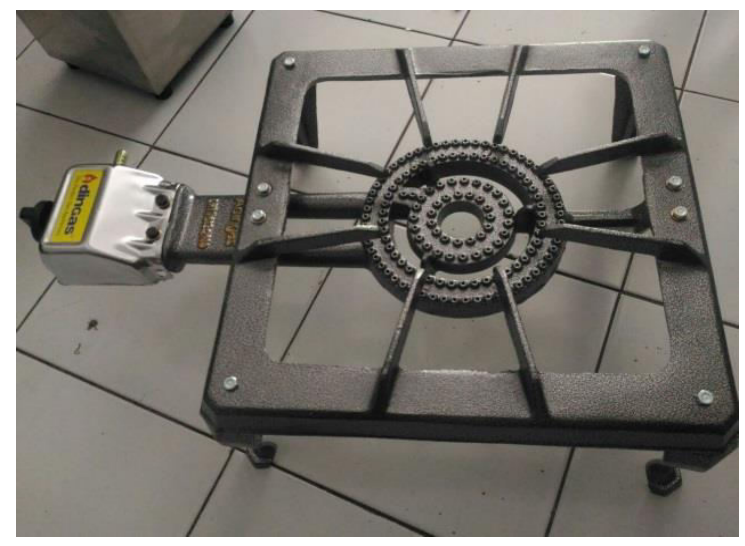

Gambar 2. Kompor Jos

\section{Peningkatan kapasitas dan efisiensi pemotongan paru sapi beku}

Alih teknologi pemotongan paru sapi menggunakan mesin pemotong daging (meat slicer) dapat meningkatkan kapasitass pemotongan karena yang sebelumnya memakan waktu pemotongan 4-6 jam utnuk $10 \mathrm{~kg}$ paru, menjadi hanya 1 perlu waktu 1 jam saja. Selain itu juga lebih efisien karena ketebalan irisan lebih seragam, pengoperasian mudah dan tidak memerlukan tenaga yang besar. Tabel 1 menunjukkan hasil pemotongan paru sebelum dan sesudah alih teknologi menggunakan mesin pemotong daging. 


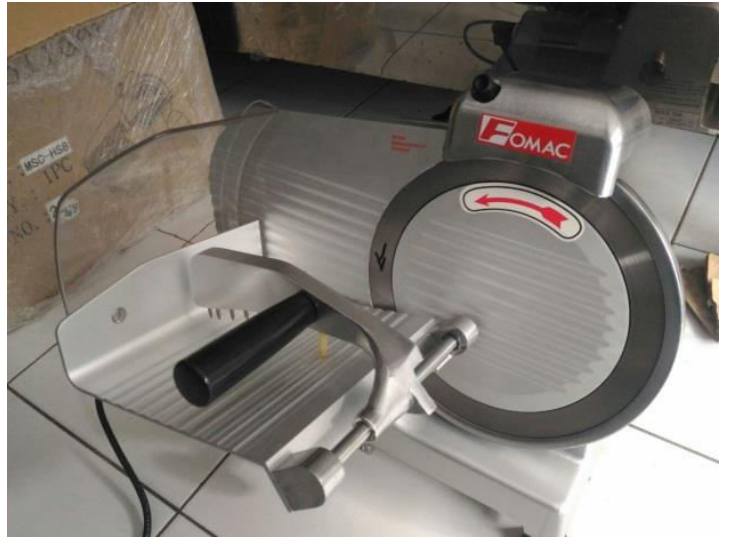

Gambar 3. Mesin pemotong daging

Tabel 1. Peningkatan kapasitas produksi Keripik Paru

\begin{tabular}{lll}
\hline \multicolumn{1}{c}{ Luaran } & \multicolumn{1}{c}{$\begin{array}{c}\text { Sebelum } \\
\text { alih } \\
\text { teknologi }\end{array}$} & $\begin{array}{c}\text { Setelah } \\
\text { alih } \\
\text { teknologi }\end{array}$ \\
\hline $\begin{array}{l}\text { Peningkatan } \\
\text { kapasitas } \\
\text { pemotongan }\end{array}$ & $\begin{array}{l}\text { jam } \\
\text { pe } / 4-5\end{array}$ & $\begin{array}{l}10 \mathrm{~kg} / 1 \\
\text { jam }\end{array}$ \\
$\begin{array}{l}\text { Peningkatan } \\
\text { kapasitas } \\
\text { penggorengan }\end{array}$ & $1,5 \mathrm{~kg} / 1$ jam & $1,5 \mathrm{~kg} \mathrm{/}$ \\
\hline
\end{tabular}

\section{Peningkatan kapasitas pemarutan kelapa}

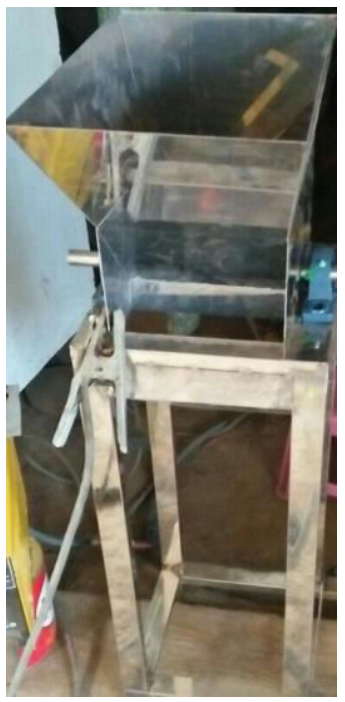

(a)

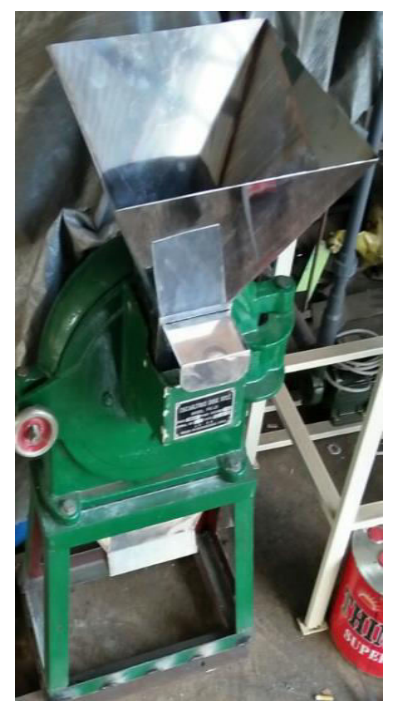

(b)
Gambar 4. (a) Mesin pemarut kelapa dan (b) mesin penggiling gula

Proses pengolahan undruk yuyu adalah dimulai dengan pemarutan kelapa dan pembuatan santan. Dalam satu hari produksi Mitra 2 membutuhkan kelapa sebanyak 3 butir kelapa yang membutuhkan waktu pemarutan sampai 15 menit. Namun setelah menggunakan pemarut listrik maka kapasitas pemarutan menjadi meningkat, untuk 3 butir kelapa hanya memerlukan waktu 2 menit. Ketika permintaan meningkat maka penggunaan pemarut listrik akan sangat membantu proses produksi untruk yuyu.

\section{Peningkatan kapasitas penepungan gula}

Proses penggilingan gula untuk pembuatan untruk yuyu menggunakan mesin penggilingan menjadi lebih efisien karena Mitra 2 tidak perlu lagi bolak-balik ke tempat jasa penggilingan gula dan dapat mengurangi biaya produksi karen tidak ada lagi biaya untuk jasa penggilingan. Gambar 4.b menujukkan gambar mesin penggiling gula. Selain itu juga dapat menigkatkan kapasitas penggilingan gula yaitu dengan gula pasir sebanyak $6,5 \mathrm{~kg}$ untuk rata-rata produksi per hari, hanya memerlukan waktu sekitar 10 menit saja. Biasanya Mitra 2 menggiling sendiri sekaligus dalam jumlah agak banyak untuk stok beberapa kali produksi berikutnya sehingga tidak perlu berkali-kali menggiling.

\section{Peningkat kapasitas pengadukan adonan untruk yuyu}

Proses pengadukan menggunakan mixer rumah tangga biasa memakan waktu 1 jam karena kapasitas pengadukan 1,5 kg untuk 15 menit. Sedangkan per hari kurang lebih membutuhkan adonan tepung sebanyak $6 \mathrm{~kg}$. Namun setelah introduksi menggunakan planetary mixer dengan kapasitas hingga 15 liter maka adonan tepung sebanyak $6 \mathrm{~kg}$ dapat sekaligus diaduk dengan waktu yang lebih singkat yaitu 15 menit dan tidak memerlukan banyak tenaga karena proses pengadukan menggunakan planetary mixer tidak perlu memegang handle mixer. Sehingga penggunaan planetary mixer ini meningkatkan kapasitas pengadukan dan lebih efisien. Gambar 5 menunjukkan proses pengadukan menggunakan planetary mixer. Tabel 2 menunjukkan peningkatan 
pemarutan, penggilingan dan pengadukan dalam produksi untruk yuyu sebelum dan sesudah alih teknologi.

Table 2. Peningkatan kapasitas produksi Untruk Yuyu

\begin{tabular}{lcc}
\hline \multicolumn{1}{c}{ Luaran } & $\begin{array}{c}\text { Sebelum } \\
\text { alih } \\
\text { teknologi }\end{array}$ & $\begin{array}{c}\text { Setelah alih } \\
\text { teknologi }\end{array}$ \\
\hline $\begin{array}{l}\text { Peningkatan } \\
\text { kapasitas pemarut }\end{array}$ & $\begin{array}{c}3 \mathrm{butir} / 15 \\
\text { menit }\end{array}$ & $\begin{array}{c}3 \mathrm{butir} / 2 \\
\text { menit }\end{array}$ \\
$\begin{array}{l}\text { Peningkatan } \\
\text { kapasitas } \\
\text { pengadukan }\end{array}$ & $\begin{array}{c}6 \mathrm{~kg} \\
\text { tepung/ja } \\
\text { adonan }\end{array}$ & $\begin{array}{c}6 \mathrm{~kg} \\
\text { tepung/15 } \\
\text { menit }\end{array}$ \\
$\begin{array}{l}\text { Peningkatan } \\
\text { kapasitas } \\
\text { penepungan } \\
\text { pasir }\end{array}$ & $\begin{array}{c}6.5 \mathrm{~kg} / 1.5 \\
\text { gula }\end{array}$ & $\begin{array}{c}6.5 \mathrm{~kg} / 20 \\
\text { menit }\end{array}$ \\
\hline
\end{tabular}

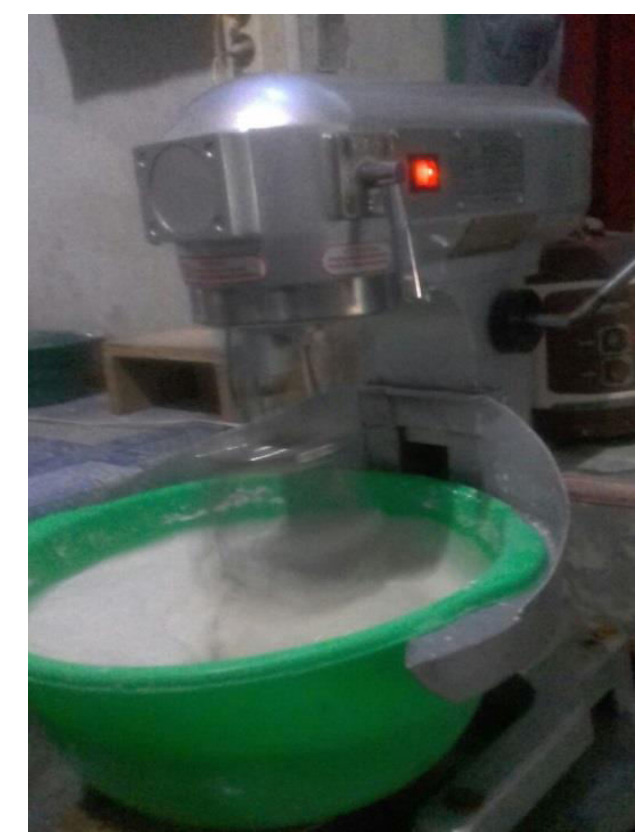

Gambar 5. Pengadukan adonan menggunakan planetary mixer

\section{KESIMPULAN}

Capaian dari program IbM ini adalah peningkatan kapasitas proses produksi keripik paru dan untruk yuyu. Peningkatan kapasitas produksi adalah pada proses pengirisan paru sapi karena mekanisasi menggunakan mesin pemotong daging sehingga dapat mengiris lebih cepat, dalam jumlah banyak serta lebih mudah. Efisiensi produksi untruk yuyu tercapai dengan penggunaan mesin planetary mixer kapasitas besar. Peningkatan kapasitas produksi juga terjadi pada proses pemaruta kelapa dan penggilingan gula untuk bahan baku untruk yuyu.

\section{UCAPAN TERIMA KASIH}

Penulis mengucapkan terima kasih atas dana Iptek bagi Masyarakat dari Direktorat Penelitian dan Pengabdian kepada Masyarakat, Direktorat Jenderal Pendidikan Tinggi, Kementerian Riset, Teknologi dan Pendidikan Tinggi dengan Nomor Penugasan: 021/SP2H/PPM/DRPM/2017, tanggal 3 April 2017, serta Lembaga Penelitian dan Pengabdian kepada Masyarakat (LPPM) Universitas Brawijaya.

\section{DAFTAR PUSTAKA}

Badan Standardisasi Nasional. 2017. Keripik Paru Sai. sisni.bsn.go.id/index.php/sni_main/sni /detail_sni/4721

Wulandari B.2012. Tugas Akhir: Konsep Pengendalian Mutu di usaha Kecil Menengah "Keripik Paru Istimewa" Bu Ganik. Universitas Sebelas Maret, Surakarta.

Goldstrand, R.E., 1988. Edible Meat Product: Their Production and Importance to the Meat Industry. In Edible Meat By-product, Advance in Meat Research.V.5.Pearson A.M and T.R. Dutson (Eds.).Elsevier Applied Sci. London and New York, pp: 1-13

Suhartini, S dan Hidayat N. 2005. Aneka Olahan Ampas Tahu. Malang : Trubus Agrisarana

Prayekti dan Herawati J.2014. Pengaruh Penerapan MSDM Terhadap Keahlian Karyawan dengan Motivasi Kerja sebagai Variabel Intervening pada UKM di Kota Yogyakarta. $3^{\text {rd }}$ Economics and Business Research Festival 13 November 2014. Fakultas Ekonomika dan Bisnis Universitas Kristen Satya Wacana 